\title{
Employer Strategies and Wages in New Service Activities: A Comparison of Coordinated and Liberal Market Economies
}

\author{
Rosemary Batt, Hiroatsu Nohara and \\ Hyunji Kwon
}

\begin{abstract}
Using survey data for call centre establishments in eight countries, we examine the relationship between wages and human resource practices. High-involvement work design and the use of performance-based pay are significantly positively related to wages, whereas intensive use of performance monitoring is negatively associated with wages. These relationships are larger among liberal economies compared with coordinated ones, but individual country differences are large and, in many cases, do not conform to expectations regarding institutional differences between liberal and coordinated market economies. The exception is Denmark.
\end{abstract}

\section{Introduction}

The relationship between employer strategies and wage outcomes has become an important topic in the literature on comparative employment and industrial relations systems. Variation in work organization and human resource (HR) practices has increased in firms within and across industries, and some research has shown that this variation is associated with differences in organizational effectiveness. Whether alternative approaches to HR management are also associated with differences in wage levels is a recent focus of debate, but empirical studies are few, the results are inconclusive, and most rely primarily on manufacturing settings and on data from the United States (Handel and Levine 2004). There are no studies that have examined this question from a comparative international perspective.

In this article, we are interested in two questions. First, to what extent do the earnings of workers reflect differences in employers' approaches to organizing work and HR practices? Second, how does employer use of HR practices and their relationship to pay vary across countries with different national institutional environments? Here, we are interested in the intersection between management practices and the institutional environment in which companies operate. We examine these questions for new service activities in call centers in coordinated and liberal market economies. By focusing on one type of service activity and one occupational group, we are able to reduce heterogeneity and more closely compare 'apples and apples' across countries. Call centers are an appropriate setting for this study because they are a growing source of employment; and they are representative of new types of service activities that are shaped by digital technologies, are highly mobile, and operate outside of traditional industry boundaries and labor market institutions. These conditions put downward pressure on wages and employment security, raising concerns that 'new economy' jobs may not sustain middle class living standards. This is a particular concern for policy makers who have promoted these jobs as a solution to unemployment and economic development.

An international comparative study of this sector can shed light on the convergence-divergence debatethe extent to which globalization is leading to a convergence in employment models or national institutional differences remain salient (Hall and Soskice 2001). If this emerging sector conforms to the patterns found in past research on manufacturing, then we have some evidence that national institutions are resilient in the face of market liberalization. We would expect to see less variation in HR practices and wage levels in coordinated economies, where industrial relations systems are relatively centralized, than in liberal economies, where they are relatively decentralized. With fewer labor market constraints, employers in liberal economies are likely to have more opportunities to experiment with alternative approaches to labor-for example, by creating more specialized and differentiated job structures that price labor according to its human capital content or value added. By contrast, unions in coordinated economies may have more power to influence the organization of work and HR practices; and more centralized bargaining structures would tend to limit differentiated wage structures at the workplace, even when employers introduce new forms of work organization. Centralized industrial relations systems may also constrain subcontractors, who operate outside of traditional institutions, to nonetheless conform to existing wage patterns through mandatory or normative mechanisms. However, to the extent that 
centralized systems are breaking down (Katz and Darbishire 2000), then variation in HR practices and pay systems in coordinated economies may more closely resemble patterns in liberal market economies.

This article addresses these issues by using identical establishment-level survey data from five coordinated economies (Austria, Denmark, France, Germany and Spain) and three liberal market economies (UK, Canada and US). In the next section, we discuss the relevant literature and then turn to our research methodology, findings and conclusions.

\section{Prior research}

In the comparative institutional literature, studies of pay setting have focused primarily on the role of collective bargaining and other labor market institutions, such as minimum wage laws, in shaping the level of individual wages and the degree of dispersion within countries (Blau and Kahn 1999; Calmfors and Driffil 1988). These studies utilize national data on individual wages and consider the effects of different institutional structures.

A more recent approach - the one taken in this article - is to examine organization level processes that help explain the compensation that workers receive. This research is consistent with the literature on indeterminacy in wage setting (Lester 1952), which emphasized that considerable wage variation exists among similar occupational groups located in the same labor market. Internal labor market theory posited that wages differ across similar employees in firms in the same industry because employers take into account norms and internal equity in setting wages. Firm-level differences in the wages of similar occupational groups persist over time (Doeringer and Piore 1971; Levine et al. 2003; Silvestre 1978). We also draw on strategic HR studies, which have shown that employers have considerable choice in the type of HR systems they adopt, even for employees in the same occupational group (Osterman 1987) and establishments operating in the same product market (Appelbaum et al. 2000; Batt 2002; Cappelli 1999).

This organizational approach has gained recent attention because the decline of union coverage in most countries has opened up space for managerial prerogative to shape employment systems, with greater use of individual contracts and performance-based pay (Brown et al. 2003; Marsden et al. 2007). Market liberalization has also increased competition, providing incentives for employers to reorganize work; and employee involvement and group-based work have diffused across countries, including Britain (Millward et al. 2000), the USA (Osterman 2000), France (Coutrot 2000; Greenan 1996) and others.

While no consistent theoretical framework exists for organizational studies of wage determination, several studies have focused on differences in work organization - in particular whether firms adopt traditional taylorist forms of work or whether they use employee involvement or 'high involvement' approaches (e.g. greater employee discretion and involvement in off-line or on-line teams) (Handel and Levine 2004; Osterman 2006). Drawing on the logic of human capital theory, these studies suggest that if employee involvement or collaborative forms of work require firm-specific skills or higher general skills (better communication skills), then workers may receive higher wages. Firms may combine these practices with more rigorous selection criteria and/or firmprovided training to create a higher-skilled workforce. However, if better human capital is the only source of higher wages, then the wage premium associated with high-involvement work organization would be reduced or eliminated once controls for human capital are included in multivariate analyses.

A related argument is that high-involvement work organization makes more productive use of employees' skills and abilities, holding human capital constant. For example, systems that allow employees rather than supervisors to solve daily work problems are more productive because workers have more tacit knowledge of production to make better operational decisions. It is not the level of human capital alone, but the way that it is used that creates higher productivity and could yield higher wages if employees have sufficient bargaining power. Still other theories emphasize that productivity gains associated with new team-based forms of work are the result of labor intensification and peer monitoring to enforce group performance norms (Barker 1993).

The empirical evidence linking pay levels to work organization, however, is mixed. Handel and Levine (2004) reviewed the literature and concluded that employee involvement practices are associated with modestly higher wages; but the significance of findings varies considerably by study methodology. Studies using national data provide inconsistent results (Bauer and Bender 2001; Forth and Millward 2004; Handel and Gittleman 2004). Studies of manufacturing alone provide somewhat stronger positive results (Cappelli 1996; Osterman 2006), although Black et al. (2004) found no relationship between employee involvement and manufacturing wage levels. 
Industry-specific studies provide stronger results than general manufacturing studies, perhaps because they minimize sample heterogeneity and are able to measure and interpret the meaning of work practices more accurately. Evidence that the use of high-involvement practices is associated with higher productivity comes from industry-specific studies in manufacturing (e.g. Appelbaum et al. 2000; Arthur 1994; MacDuffie 1995) and services (banking, Bartel 2004; telecommunications call centers, Batt 2002). Researchers have found significant positive relationships between high-involvement practices and wage levels in apparel plants (Hamilton et al. 2003), auto parts suppliers (Helper et al. 2002), and steel and apparel plants, but not medical electronics (Bailey et al. 2001). Studies of call centers have shown that quality and sales productivity are higher in US service centers that use selfdirected groups because they are better able to solve customer problems and adapt to changing information systems (Batt 1999); also wage levels are higher in centers that provide employees with more discretion for handling tasks and customer inquiries (Batt 2001). Thus, both theory and empirical evidence suggest that establishments in the same product market that make greater use of high-involvement work organization are likely to pay higher wages to their core workforce.

In addition to how work is organized, recent research has also examined whether wages vary in relation to different approaches to performance management. Two approaches are noteworthy: behavioral-oriented and outcome-oriented systems (Eisenhardt 1988). These systems have been viewed, alternatively, as providing control mechanisms to reduce shirking or incentives to induce effort (Bryson and Forth 2006: 20).

Behavioral systems control employee behavior through ongoing monitoring and enforcement of rules and tend to be found in easy-to-monitor jobs involving simple tasks. These approaches are consistent with traditional taylorist forms of work design, where tasks are simple, skill requirements are low and work is designed around individual jobs. Work design in call centers fits this description and electronic monitoring technology facilitates real-time monitoring of individual tasks. Heavy reliance on electronic monitoring also signals distrust to workers. For these reasons, we would expect the intensive use of monitoring systems to be associated with lower wages. Alternatively, the theory of compensating wage differentials suggests that intensive monitoring creates onerous working conditions that should be compensated at a higher rate; and some research has shown a positive relationship between high stress levels and wages (French and Dunlap 1998).

Outcome-oriented systems, by contrast, usually entail the use of performance-based pay and tend to be found in hard-to-monitor jobs - for example, where tasks are more complex or work requires independent discretion, problem solving or group work. In other words, high-involvement work is likely to be accompanied by performance-based pay because it induces discretionary effort. Some empirical studies have shown a positive relationship between performance-based pay and wages, but that relationship depends importantly on the formula for payouts, which if perceived by workers as unfair, may de-motivate them rather than the opposite. While a wide variety of incentive pay schemes have been found in call centers (Fernie and Metcalf 1998), the use of individual commission pay (a form of piece work) is the most common. Greater use of commission pay is likely to be associated with higher establishment-level wages because it motivates effort and because those employees who do not function well under this system tend to quit or be fired.

While the literature suggests that employers tend to adopt one form of incentive system or the other, in reality employers may use some combination of both, depending upon the performance outcome of interest. In the context of service environments, for example, employers are concerned about economic outcomes, such as sales, which are amenable to outcome-oriented performance metrics; but they are also concerned about the quality of the service process and its effect on customers, which are easily measured by electronic monitoring systems. As a result, wage levels of employees in this environment should reflect the net effect of using these two approaches to performance management.

In general, then, there are theoretical reasons to suggest that wages should vary in relation to different approaches to work organization and performance management - because different approaches alter the skill requirements of jobs, the effort level of employees and the quality and productivity of employee output. However, empirical studies need to be conducted at the level of specific product markets and occupational groups in order to accurately measure the particular HR practices that are relevant to economic outcomes.

\section{Comparative institutional perspectives}

The literature on the relationship between HR practices and economic outcomes, however, has largely ignored the rich comparative institutional literature on varieties of capitalism, which suggests that these 
relationships are likely to vary across countries with distinct economic systems (Jackson and Deeg 2006). National systems differ in how they organize capital, labor and product markets and welfare states, and these provide economic actors with different opportunities, constraints and institutional resources (Streeck and Thelen 2005). The simplest approach to varieties of capitalism, which distinguishes between coordinated and liberal market economies (Hall and Soskice 2001), provides a useful point of departure because it allows us to test the statistical significance of alternative hypotheses (Jackson and Deeg 2006: 32). For example, is the relationship between HR practices and wages significantly different between coordinated and liberal market economies; and is it significantly different among countries in each of these groups?

Liberal market economies (LMEs), such as the USA, Canada and the UK, rely primarily on markets and prices to co-ordinate economic activity. Their decentralized industrial relations systems allow employers considerable choice in designing work and HR practices. While unions favor solidaristic employment and wage policies that would limit pay variation based on HR practices, unions in these countries negotiate contracts at the firm or establishment level, which produces considerable variation in HR practices and pay across these units. Moreover, low union density and power limit union capacity to influence managerial prerogative in the design of jobs and HR practices, and even how employers price labor in differentiated jobs. Unions in the USA, for example, have little control over whether employers introduce team-based work systems or performance-based pay, although some research shows that unions in the UK have more say in these respects (Pendleton et al. 2009).

Coordinated market economies (CMEs), in theory, rely more on political processes of negotiation, persuasion and consensus building in the establishment of work and pay systems. Union power coupled with works councils in organizations may constrain employer choice of work and HR practices, as some recent studies of call centers have demonstrated (Doellgast 2008). Also, in more centralized industrial relations systems, unions are more able to negotiate lower wage dispersion within and across occupations, firms or industries. Past empirical research has shown that wage variation is much lower in centralized coordinated economies than in decentralized liberal market economies (Blau and Kahn 1999; Calmfors and Driffil 1988).

However, market liberalization in coordinated economies has allowed employers to experiment with alternative work and HR practices in order to compete more effectively. To do so, they have pushed for more decentralized approaches to wage bargaining. As a result, most countries have undergone considerable decentralization in collective bargaining (Katz and Darbishire 2000), but differences between coordinated and liberal market countries remain. Most advanced countries have also experienced de-unionization, as traditionally unionized manufacturing sectors have been superseded by new service sectors with weak representation, and as new generations with less attachment to the labor movement have entered the workforce. However, the relative decline has been higher in more decentralized systems than centralized ones (Visser 2006). These trends suggest that differences between coordinated and liberal market industrial relations systems remain considerable, and therefore, that meaningful differences in the patterns of use of HR practices and their relationship to pay should exist between these two groups of countries.

In addition, among the coordinated countries, differences in the extent of decentralization in industrial relations systems are marked, despite pressure from the European Union for integrated social and labor market policy (Marginson et al. 2003; Traxler 2003). The multi-level bargaining systems in these countries differ in terms of union density, the level at which bargaining occurs, and whether negotiated wages are extended by law to other employers. Austria, France and Spain continue to have relatively high levels of centralization and union coverage, with mandatory extensions of agreements to all employers (Caroli and Gautie 2008). Nonetheless, French employers make extensive use of individual performance-based pay (Marsden et al. 2007)-beyond the use of profit-sharing, which has been supported by state fiscal policy - although the percentage of total compensation due to performance-based pay is less than 10 per cent. 1 Denmark continues to have high levels of union density and employer compliance with negotiated agreements via normative rather than mandatory mechanisms (Westergaard-Nielsen 2008). Germany, by contrast, has experienced considerable erosion in labor market institutions and compliance with collective bargaining as some employers have dropped their membership in industry associations or insisted on 'hardship clauses' that allow them to escape from agreements for economic reasons (Bosch and Weinkopf 2008; Ochel 2005).

Similarly, among liberal market economies, differences exist in their HR and industrial relations systems that are likely to influence the relationship between HR practices and pay. For example, the USA has much lower union density and a lower minimum wage level than Canada or the UK. Thus, while we expect to find significant 
differences between coordinated and liberal economies overall, we also expect to find variation in the relationship between work practices and pay levels among countries in each of these groupings.

\section{Expected findings}

In sum, we expect that differences in establishment-level earnings will reflect variation in work organization and performance management systems, over and above the effects of human capital. Centers that make greater use of high-involvement work organization and performance-based pay should offer higher wages, while greater use of intensive monitoring systems should be associated with lower wages.

Beyond the direct relationships between HR practices and wages, national industrial relations systems should have important moderating effects on these relationships. First, in coordinated economies, where union coverage is greater and industrial relations systems are more centralized, we would expect the incidence of particular work and HR practices to be different from liberal market economies. Unions and works councils typically have urged the adoption of high-involvement forms of work design, but have resisted the use of intensive monitoring or performance-based pay. Therefore, compared to liberal economies, we would expect coordinated economies to make greater use of high involvement work design but less use of intensive monitoring (Doellgast et al. 2009; Holman et al. 2009) or performance-based pay. Second, in coordinated economies, where unions have more power to secure solidaristic wage policies, we would expect the relationship between HR practices and earnings levels will be smaller.

We also expect to see variation in these relationships among both the coordinated and liberal market countries. Where de-unionization and decentralization in collective bargaining have occurred to a greater extent in some countries, we would expect to see a larger correlation between HR practices and earnings levels. Based on existing evidence of changes in industrial relations systems, we would expect Germany to stand out as an exception to the pattern among coordinated economies, and the USA to stand out as the most extreme case of variation among liberal market economies.

\section{Research methodology 2}

The survey used in this study is an establishment-level survey, administered to the senior manager of each call centre. It has many questions in common with the Workplace Employment Relations Survey (WERS) in Britain and the comparable workplace industrial relations survey (REPONSE) in France, including questions about markets, organizational and demographic characteristics, work organization, HR practices, wages and collective bargaining coverage. The call centre survey also includes some sector-specific formulations of these questions.

Given that the survey relies on a single respondent (typically the general manager), we took a number of steps to improve its reliability: we asked questions only about the 'core' occupational group (call centre agents) and asked respondents to focus on the employee group serving the largest group of customers. This eliminates ancillary employees and those who serve special groups of customers. We did extensive field research in order to construct questions phrased in the language that call centre managers typically use - items such as electronic monitoring, call-handling time and call centre-specific technology. We tested these questions with managers in the field to make sure they were readily able to answer them. In addition, most of the survey questions came from prior national surveys of call centers, tested in the UK and the USA, with modifications for some items to improve clarity. Issues of reliability also may be less in this context because call centers are quite standardized operations and the typical establishment size is relatively small-less than 100 employees in our international dataset. Thus, the general manager is likely to have a reasonable understanding of what is going on in his or her workplace. Recent studies have shown that establishment-level surveys have much higher levels of reliability than those administered at higher levels of the organization (Gerhart et al. 2000).

A second methodological challenge was to ensure consistency across countries while also allowing modifications to accommodate different national institutional contexts. Each country team started with the survey developed in the USA and the UK, translated it, tested it with focus groups in the field and made modifications to the wording of questions where needed. Some questions that were not applicable were deleted and others were added; but the overwhelming bulk of questions were identical across the countries.

We also emphasized a consistent approach to sampling and survey administration, although some variation occurred. Appendix 1 provides information on the samples, sampling frames, survey administration and 
response rates for each country in the study. Identifying the population of establishments from which to draw the sample was the most difficult step because most governments do not collect call centre statistics. Each country team chose the sample from the largest available list of call centers-typically the membership list of the national call centre employers' association, supplemented by other sources. However, one advantage of studying this sector is that the number of establishments in most countries is relatively small-less than 3,000 (with the exception of the Canada, the USA and the UK) - so that the proportion of the sample to the overall population of centers was relatively high. The average response rate was 59 per cent (unweighted average) and was 60 per cent for the entire sample (weighted average). It ranged from 40 per cent in the UK to 77 per cent in Canada (see Appendix 1).

In general, using employers' association lists to identify the population of call centers biases the sample towards more professionally operated centers because the association members tend to be part of large national or multinational corporations. This leads us to expect that the sample, in general, is biased towards larger, more established centers, with more formalized HR practices and higher wage levels than would be expected if the samples were drawn from the entire population of centers.

\section{Measures}

The measures for the variables in this analysis are found in Appendix 2. We have used organization-level data (not weighted by the number of employees) because our focus is on employer strategies for HR practices and wages at the organization level. The dependent variable is the log of annual earnings (in US\$), defined as 'the gross annual earnings of the "typical" or median full-time core employee'-meaning that about half the core employees are paid more and about half are paid less. Gross annual earnings includes total earnings before deductions and taxes. It includes wages, bonuses, commissions and profit-sharing. It excludes overtime pay, benefits such as pensions and health, and deferred compensation such as stock options. In the course of field work, our country teams did not encounter the use of stock options for call centre workers. While most wage studies use hourly wages, we use gross annual earnings because an important part of the earnings of these workers comes from performance-based pay, especially commission pay. This is not captured in hourly wages. Our measure of earnings is consistent with other economic studies of wages at the organizational level (Batt 2001; Osterman 2006).

To measure our independent variable of high-involvement work organization, we used two dimensions: the level of employee discretion and the percentage of workers participating in offline or on-line groups. Discretion is a scale based on the mean of eight items measured on a likert scale of 1-5: discretion over tasks, tools, pace of work, breaks, work methods, what to say to customers, handling additional customer requests, handling customer complaints (alpha $=0.77$ ). Participation in off-line problem-solving groups and on-line self-directed groups is the combined average percentage of employees involved in either of these groups. We standardized the variables before creating a mean index (a z score, with mean zero), which was then used to create interaction terms with country indicator variables.

Our measure of performance management includes two variables: the intensity of performance monitoring and use of performance-based pay. Monitoring intensity is measured by the mean of three items: how often core employees receive statistics on performance; how often their calls are listened to by supervisors; and how often they get feedback on phone technique. The frequency scale is from 1 (never) to 8 (daily). We standardized this scale to mean zero and then created interaction terms with country indicator variables.

The incidence of performance-based pay is an indicator variable, with 1 representing those establishments that make any use of either individual or group-based pay. We created interaction terms by multiplying this indicator with the country indicator variables. We also examined the use of individual and groupbased pay separately, but found no meaningful differences in the results, so we report only the analyses for the combined variable. Control variables for human capital and demographic characteristics include indicator variables for the years of formal education of the typical call centre worker, investment in firm-specific training and the percentage of the workforce that is female. For formal education, the three categories are 16 years of education or less (omitted category), 18 years or less, or holding a college degree. The level of firm-specific training is measured by the number of weeks required for the typical new hire to become proficient in the job.

Control variables for institutional, or organizational and market characteristics include whether the centre is covered by a collective bargaining agreement, whether it primarily serves large business clients or other customer segments (omitted category) and whether it is owned by the primary firm (in-house) or a subcontractor 
(omitted category). In addition, we controlled for sector (financial services; telecommunications services; or other, the omitted category). In all countries, the largest proportion of call centers is found in the financial services or telecommunications industries (Holman et al. 2007). Other controls include establishment size (natural log of the number of call centre agents), establishment age (natural log of years), type of technology used (an index of five types of call centre technology for interacting with customers: email, fax, web enablement, electronic customer relationship management and Voice over Internet Protocol), primary task activity (whether service only, or service and sales) and primary call type (whether inbound or outbound).

\section{Data Analytic Approach}

We conducted regression analyses using the pooled international dataset in order to be able to compare the size and significance of the variable coefficients for coordinated versus liberal market economies and for each country. Because the sample sizes for each country are relatively small, we were not able to conduct individual country-level analyses that would have allowed us to compare the significance levels of coefficients across the different datasets. To estimate robust standard errors, we used a Huber correction technique, which takes into account the correlations among observations that belong to the same group (in this case, country). We then estimated two sets of equations: the first assesses the correlates of the incidence of HR practices; and the second, the correlates of annual earnings. Our incidence models have three dependent variables (high-involvement work design, performance monitoring and performance-based pay). We test whether differences in economic system (coordinated versus liberal market) or differences in national institutions (country level) are associated with different patterns of adoption of HR practices, controlling for human capital, demographic, organizational and institutional factors.

Our wage models include a series of estimations that examine the main effects for our three measures of HR plus a set of control variables. We ran separate analyses to compare the results for coordinated versus liberal market economies. To estimate country level effects, we added a set of interaction terms for HR practices * country-level indicators. Based on these analyses, we calculated the wage premium associated with each HR practice and whether each was statistically significant for coordinated versus liberal market economies and for each country in the study. Our estimated wage model includes the following terms:

$$
\text { Ln wage }=f\left(\alpha+\beta_{1} H R=\beta_{2} H C+\beta_{3} \text { ORG }+\beta_{4} \text { COUNTRY }+\beta_{5} H R^{*} \text { COUNTRY }+\varepsilon\right)
$$

where $\mathrm{HR}=$ the three main $\mathrm{HR}$ variables of interest; $\mathrm{HC}=$ a set of human capital and demographic controls; $\mathrm{ORG}=$ a set of organizational and institutional controls; COUNTRY = individual country dummies; and HR*COUNTRY = the interaction terms to test moderating effects.

\section{Findings}

To put the earnings of call centre workers in the context of the national earnings distributions in each country, Table 1 compares the median hourly wages of call centre workers to the median hourly wages of full-time workers in each country. Because no government collects national wage and employment data for call centre workers, we developed estimates based on our establishment-level data. We calculated call centre wages by taking the average of establishment-level wages, as reported by managers, weighted by the number of workers at the establishment and divided by the annual work hours for full-time workers in each country. Recall that our wage question asked about the annual earnings of the 'median' worker in each call centre; and we make the assumption here that the median worker is a full-time, regular employee. We base this assumption on our extensive fieldwork, in which we found that call centers typically relied on full time workers with standard contracts. Even though the use of non-standard contracts is higher in call centers than many other sectors, few centers rely on these contracts for the majority of their employees.

This comparison shows that the typical call centre worker earns less than the median wage in all countries: between 0.71 and 0.84 of the median hourly wage in EU countries, and just below the median in the USA and Canada (0.97 and 0.94). These estimates must be viewed with caution, however. As noted above, they may be biased upwards because our samples draw on employer association lists; but they can also be biased downwards because they compare a predominantly female workforce ( $70 \%$ female, on average) with national data for the 


\section{TABLE 1}

Median Hourly Wages, By Country: Call Centre Workers and National Workforce Compared

\begin{tabular}{llccc}
\hline & \multicolumn{1}{c}{$\begin{array}{c}\text { Local } \\
\text { currency } \\
\text { (Year) }\end{array}$} & $\begin{array}{c}\text { National } \\
\text { median } \\
\text { hourly wage }\end{array}$ & $\begin{array}{c}\text { CC workers } \\
\text { median } \\
\text { hourly wage }\end{array}$ & $\begin{array}{c}\text { Ratio: CC } \\
\text { workers } \\
\text { National } \\
\text { median }\end{array}$ \\
\hline Liberal market economies & & & & \\
US & US \$ (2005) & 14.30 & 13.84 & 0.97 \\
Canada & Canadian \$ (2005) & 18.00 & 16.87 & 0.94 \\
UK & British $£(2005)$ & 9.56 & 7.16 & 0.75 \\
Co-ordinated market & & & & \\
economies & & & & \\
Austria & Euro (2006) & 11.46 & 8.53 & 0.74 \\
Denmark & DK Krona (2005) & 164.00 & 137.00 & 0.84 \\
France & Euro (2006) & 12.53 & 9.99 & 0.80 \\
Germany: West & Euro (2004) & 14.75 & 11.85 & 0.80 \\
Germany: East & Euro (2004) & 10.73 & 8.27 & 0.77 \\
Spain & Euro (2006) & 8.00 & 5.67 & 0.71 \\
\hline
\end{tabular}

Sources: For national data on Denmark, Germany, UK, US, Gautie and Schmidt 2010; for Austria, France, Spain, European Employers Federation 2008; for Canada, Labour Force Survey 2005, Statistics Canada; For call centre workers, own calculations from Global Call Centre Survey.

Source for CC workers: GCC survey, weighted calculations. 
TABLE 2

Means and SDs of Variables: Liberal and Co-ordinated Market Economies Compared

\begin{tabular}{|c|c|c|c|c|c|c|c|c|c|}
\hline \multirow[t]{2}{*}{ Variable } & \multicolumn{4}{|c|}{ All } & \multicolumn{2}{|c|}{ Liberal market } & \multicolumn{2}{|c|}{ Co-ordinated market } & \multirow[t]{2}{*}{ Sig. } \\
\hline & Mean & $S D$ & $\operatorname{Min}$ & $\operatorname{Max}$ & Mean & $S D$ & Mean & $S D$ & \\
\hline Wage $(\ln )$ & 10.215 & 0.396 & 7.8 & 11.5 & 10.310 & 0.354 & 10.038 & 0.408 & $* * *$ \\
\hline High-involvement work (std) & -0.019 & 0.690 & -1.3 & 2.2 & -0.050 & 0.680 & 0.039 & 0.704 & $*$ \\
\hline Monitoring inten sity (std) & 0.022 & 0.976 & -2.4 & 1.9 & 0.128 & 0.934 & -0.175 & 1.022 & $* * *$ \\
\hline Performance-based pay & 0.551 & 0.498 & 0 & 1 & 0.581 & 0.493 & 0.494 & 0.500 & $* * *$ \\
\hline Performance pay: Individual & 0.450 & 0.498 & 0 & 1 & 0.454 & 0.498 & 0.441 & 0.497 & \\
\hline Performance pay: Group & 0.254 & 0.436 & 0 & 1 & 0.293 & 0.455 & 0.183 & 0.387 & $* * *$ \\
\hline Education: 18 years & 0.462 & 0.499 & 0 & 1 & 0.534 & 0.499 & 0.329 & 0.470 & $* * *$ \\
\hline College degree & 0.233 & 0.423 & 0 & 1 & 0.195 & 0.396 & 0.304 & 0.460 & $* * *$ \\
\hline Firm training (wks.) & 23.08 & 19.23 & 0 & 120 & 24.77 & 19.04 & 19.92 & 19.21 & $* * *$ \\
\hline Female $\%$ workforce & 0.692 & 0.219 & 0 & 1 & 0.674 & 0.225 & 0.724 & 0.204 & $* * *$ \\
\hline Union coverage & 0.322 & 0.467 & 0 & 1 & 0.180 & 0.385 & 0.585 & 0.493 & $* * *$ \\
\hline Large bus segment & 0.198 & 0.399 & 0 & 1 & 0.209 & 0.407 & 0.179 & 0.383 & \\
\hline In-house centre & 0.692 & 0.462 & 0 & 1 & 0.741 & 0.438 & 0.600 & 0.490 & $* * *$ \\
\hline Technology & 2.530 & 1.206 & 0 & 5 & 2.541 & 1.252 & 2.509 & 1.116 & \\
\hline Size (ln employees) & 3.985 & 1.368 & 0.5 & 8.4 & 4.154 & 1.379 & 3.670 & 1.291 & $* * *$ \\
\hline Part of larger org. & 0.819 & 0.385 & 0 & 1 & 0.827 & 0.378 & 0.805 & 0.397 & \\
\hline Age of centre (ln years) & 2.311 & 0.676 & 0 & 4.1 & 2.421 & 0.697 & 2.105 & 0.581 & $* * *$ \\
\hline Services only & 0.513 & 0.500 & 0 & 1 & 0.496 & 0.500 & 0.544 & 0.499 & \\
\hline Inbound centre & 0.824 & 0.381 & 0 & 1 & 0.856 & 0.351 & 0.766 & 0.424 & $* * *$ \\
\hline Sector: Financial services & 0.214 & 0.410 & 0 & 1 & 0.198 & 0.399 & 0.244 & 0.430 & $*$ \\
\hline Sector: Telecoms & 0.316 & 0.465 & 0 & 1 & 0.339 & 0.474 & 0.273 & 0.446 & $*$ \\
\hline Austria & 0.038 & 0.191 & 0 & 1 & 0 & 0 & 0.109 & 0.312 & \\
\hline Denmark & 0.052 & 0.223 & 0 & 1 & 0 & 0 & 0.150 & 0.357 & \\
\hline France & 0.138 & 0.345 & 0 & 1 & 0 & 0 & 0.394 & 0.489 & \\
\hline Germany & 0.085 & 0.279 & 0 & 1 & 0 & 0 & 0.244 & 0.430 & \\
\hline Spain & 0.036 & 0.186 & 0 & 1 & 0 & 0 & 0.103 & 0.304 & \\
\hline Canada & 0.229 & 0.420 & 0 & 1 & 0.352 & 0.478 & 0 & 0 & \\
\hline $\mathrm{UK}$ & 0.107 & 0.310 & 0 & 1 & 0.165 & 0.371 & 0 & 0 & \\
\hline US & 0.314 & 0.464 & 0 & 1 & 0.483 & 0.500 & 0 & 0 & \\
\hline Sample & 1,396 & & & & 909 & & 487 & & \\
\hline
\end{tabular}

LME and CME significantly different at $p<0.05=^{*} ; p<0.01=* * ; p<0.001=* * *$. 
entire workforce. In addition, they do not capture the distribution of wages, nor do they take into account nonwage benefits, which vary markedly across countries. Our purpose in offering these estimates is to provide a rough calculation of where call centre workers fit in national wage distributions: they typically do not earn wages at or above the median of their country's wage distribution, but neither are they at the bottom of the wage hierarchy in these countries.

Table 2 provides the descriptive statistics for variables used in the multivariate analyses. We present the means of variables for the entire dataset, and the averages for liberal market and coordinated market economies and whether the differences between the two are statistically significant. The means of variables by country are provided in Appendix 3. The correlation matrix for the entire dataset is provided in Appendix 4.

In Table 2, we have presented the standardized scores for high-involvement work organization and performance monitoring as these are the measures used in our equations. However, the means of the raw variables provide a more concrete sense of workplace practices, and we report them here. The average workplace is one in which managers report that workers have a moderate level of discretion (2.73 on a 1-5 scale), and about 30 per cent of the workforce is involved in some type of group work - usually offline problem solving groups. The average workplace provides feedback on monitoring about once per week; more intensive monitoring involves feedback on a daily basis or more. The use of performance based pay is quite varied: 55 per cent of centers make use of either individual or group-based pay; 45 per cent make any use of individual incentive pay; and 25 per cent make any use of group pay.

It is also noteworthy that our measures of HR practices are not highly correlated. The strategic HR research tradition typically conceptualizes HR practices as systems, with reinforcing elements. In the case of call centers, this means that, conceptually, high-involvement work design should be highly correlated with low use of performance monitoring, as the former provides substantial discretion for employees to use their independent discretion and signals managerial trust in workers' ability to respond to customers appropriately. By contrast, the intensive use of performance monitoring and feedback creates an environment of mistrust, in which employees feel that supervisors are routinely overseeing their interactions with customers. In our data, however, the correlations between high-involvement work design and performance monitoring are modest, at only -0.23 . The correlation between high-involvement and performance-based pay is only 0.07 , and that between monitoring and performance-based pay is $\mathbf{0 . 0 4}$. When we ran these correlations on a country by country basis, we found little variation in results. This suggests that call centers do not offer the kind of coherent approach to HR practices that others have found to be prevalent in manufacturing settings, such as lean production. This may be because they are new service activities operating in highly uncertain market environments, and managers are experimenting with a variety of alternative HR practices. Thus, the data support our approach, which is to examine these practices separately.

Descriptive statistics show that almost 50 per cent of establishments typically hire employees who have completed education up to age 18; one-quarter of the centers typically hire workers with a college education. The average centre has a workforce that is 69 per cent female; and the time needed for a newly hired worker to become proficient averages 23 weeks. Call centers are flat organizations with little variation in the percentage of the workforce that is managerial (on average, 13 per cent). Establishments in financial services represent 22 per cent of the sample, and those in telecommunications, 33 per cent. Seventy per cent of centers are in-house; 82 per cent are part of a larger corporation; 80 per cent are inbound rather than outbound centers; and about 50 per cent of worksites provide service only, while the other 50 per cent provide sales or sales and service. The typical call centre in 2005 was 8 years old, with the USA as an outlier with a median of 12 years.

\section{Differences between Coordinated and Liberal Market Economies}

Table 2 also shows that there are statistically significant differences between the coordinated and liberal market countries on many of the variables used in the analysis. As expected, coordinated economies score significantly higher on the high-involvement work index and significantly lower in performance monitoring and performance-based pay, although the usage rates for individual incentive pay do not differ. In the liberal economies, 58 per cent of centers make some use of performance-based pay, compared with 49 per cent in coordinated economies. About 45 per cent of establishments in both groups make use of individual incentive pay, but a larger percentage of centers in liberal market economies use group-based pay (29 per cent of centers) compared with coordinated economies (18 per cent). 
Overall, the USA is an outlier in the use of performance-based pay, with 75 per cent of centers making any use of the practice. For all other countries, the usage rate varies from an average of 35 per cent in the UK and Denmark to 58 per cent in France. Perhaps surprisingly, Canada and the UK resemble the coordinated economies more than they do the USA, while France more closely resembles the USA in the use of this practice. The patterns for Britain are consistent with Bryson and Freeman's (2006) analysis of the 2004 British WERS data, where they reported that one-third of workplaces made use of individual performance pay and about one-quarter used groupbased pay. Marsden and colleagues' (2007) analysis of the WERS and French REPONSE surveys also found that, compared with Great Britain, France makes greater use of performance-based pay not only for the managers/ professional workers but also for the production/clerical workers.

In coordinated economies, a higher proportion of centers use college-educated workers, which may help explain why the amount of firm-specific training used (the time to become proficient on the job) is lower. Union coverage in coordinated economies is substantially higher (59 per cent vs. 18 per cent) and the size of establishments is smaller (an average of 94 agents compared with 170) than in liberal market economies.

We now turn to our regression analyses. In Table 3, we present the results of our incidence models. 3 Here, we are primarily interested in whether location in a coordinated versus liberal market economy makes a difference (models 1, 2 and 3) or whether there are specific country-level effects (models 4, 5 and 6). These equations control for all of our human capital, demographic, organizational and institutional variables. The omitted country is the USA. The results are partially consistent with our expectations: On average, coordinated economies are significantly less likely to use intensive performance monitoring, as expected, but otherwise they are not significantly different from the liberal market group. The country-level analyses help explain these results, as we find considerable variation among the coordinated countries as well as among the liberal market economies. For example, Austria, Denmark and Germany make significantly greater use of high-involvement work design and lower use of monitoring and performance-based pay than does the USA (the omitted category). By contrast, France and Spain resemble the USA in their adoption of a more taylorized approach to work organization and the use of performance-based pay (in fact, France is significantly less likely than the USA to adopt high-involvement design).Among liberal economies, Canada and the UK follow the US pattern of work organization, but their use of performance-based pay is actually lower than that found in all of the coordinated economies except Denmark. Thus, for our understanding of the extent of adoption of these HR practices, coordinated and liberal market categories are not very useful for describing patterns of variation. We interpret these results in the discussion section below.

\section{Results of Wage Analyses}

In Table 4, we present the results of our wage models for the pooled dataset (model 1), coordinated economies (model 2) and liberal market economies (model 3). The overall equation explains a substantial amount of variance (56 per cent) in establishment-level wages in this (emerging) service sector. Before turning to the main effects, it is worth noting that many of the control variables are significant and consistent with expectations. In all of the analyses, the human capital and demographic characteristics are highly significant. Establishments that typically employ higher-educated workers pay higher wages, while those that hire more women pay lower wages. Union workplaces pay a 12 per cent wage premium on average, 4 which is consistent with recent research that shows a continued wage premium in liberal market countries and a growing wage premium in some coordinated economies where industrial relations systems have become more decentralized, as in Germany (Batt and Nohara 2009; Bosch and Weinkopf 2008). Recent evidence also shows that even where union density has declined and product competition has increased, union workplaces have been more able to prevent wage reductions, compared to non-union sites (Blanchflower and Bryson 2003). In-house centers pay an 8.5 per cent wage premium on average, compared with subcontractors - a finding that is consistent with the traditional literature on labor market segmentation between primary and secondary firms (Piore 1979).

Turning to the workplace variables of interest, we find that high-involvement work organization and both performance management variables are statistically significantly related to wages, for the sample as a whole, after controlling for a full set of human capital, demographic, organizational and institutional factors (Table 4, model 1). Wage levels are significantly positively related to high-involvement work design $(0.066, p<0.05)$, negatively related to performance monitoring $(-0.050, p<0.01)$ and positively related to performance-based pay $(0.057, p<$ $0.001)$. A one-standard deviation increase in the high-involvement work index is associated with 6.6 per cent 
higher wages $(p<0.05)$, while a one-standard deviation increase in the monitoring scale is associated with 5.9 per cent lower wages $(p<0.01)$. In addition, those establishments that use performance-based pay offer 5.7 per cent higher wages $(p<0.001)$ relative to those that make no use of these pay practices. These estimates represent the average for the entire dataset.

In model 2, which estimates the equation for the liberal market economies, all three HR practices are statistically significant for this group, and larger in size and significance than for the sample as a whole: highinvolvement work $(0.082, p<0.001)$, monitoring $(-0.063, p<0.001)$ and performance pay $(0.059, p<0.001)$. Model 3 performs the same analysis for the coordinated economies: Monitoring intensity $(-0.025, p<0.05)$ and performance-based pay $(0.038, p<0.05)$ are significantly related to wages, but the work organization index is not. The size and significance of all three relationships is lower than for the liberal market group, although our tests of significance showed that only the coefficients on monitoring intensity are statistically significantly different between the liberal market and coordinated market groups. 5

In Table 5, we turn to our analyses of whether the relationship between wages and HR practices is significant for each of the eight countries in the study. Table 5 presents four models. Model 1 is the basic equation with controls for countries; model 2 estimates the interaction between high-involvement work organization and country; model 3 does the same for performance monitoring; and model 4, for the use of performance-based pay. In the analyses with interaction terms (models 2-4), the coefficients on the main effect variables represent the value for the omitted country (in this case, the USA).

The results show that the main effect coefficient for high-involvement work organization is over two times larger in model 2 than in model 1, indicating that work organization explains substantially more variance in pay in the USA compared with the average for the entire sample. The country interactions with work organization show that, in all cases, the pay premium for high involvement is lower than for the USA and is statistically significantly different from the USA. The exception is Germany, where the negative coefficient is not statistically significant. The pay penalty attached to monitoring intensity is higher in the USA than for countries on average (-.079 in model 3 compared with -0.050 in model 1$)$, a finding driven primarily by the significantly different lower penalties in Denmark, France and the UK (see the interactions in model 3). Finally, the premium for performancebased pay is larger in the USA than the average for all countries ( 0.103 in model $4 \mathrm{vs.} 0.057$ in model 1$)$; and the differences from the USA are statistically different for all countries but Germany and Spain, as confirmed by the interactions in model 4.

To calculate the actual size of the coefficient on the three variables of interest for each country, we summed the main effect (for the USA) and the interaction term for the country. Thus, for example, the main effect for high-involvement work organization is 0.144 for the USA, while the coefficient for Austria is $0.072(0.144-$ 0.072). However, the analyses in Table 5 do not indicate whether the coefficient for each country (0.072 for Austria) is statistically significant for explaining the variance of pay within Austria. To test whether the effect within each of the other countries is statistically significant, we repeated the regression analyses for models 2-4 and omitted a different country each time. For each equation, the main effect indicates whether the coefficient is significant in explaining variation within the omitted country. We do not show each of these regressions, but have compiled the results in Table 6.

Table 6 shows the coefficients for the wage premia or penalties associated with work organization, monitoring and performance-based pay for the liberal market economies as a whole, the coordinated economies as a whole, and each of the countries in these two groups. The average scores for the liberal and coordinated market economies are taken from Table 4. As noted above, the coefficients are larger in size and significance for the liberal market group as a whole, but only the differences for monitoring intensity are statistically significant between the two groups.

Beyond these general patterns, the coordinated and liberal market categories do not provide much explanatory power. Almost all of the countries in the study have significant wage premia (or penalties) associated with most of the practices we analyzed, implying an overall labor market liberalization story. First, highinvolvement work organization is positive in all cases except for France, albeit non-significant in Denmark. Second, monitoring intensity carries a sizable wage penalty in all cases but Denmark and France, where it is insignificant. Third, performance-based pay is always positive, though not always significantly so. Thus, even among coordinated economies, we find considerable wage variation at the workplace level linked to different approaches to HR management. This suggests that, with some exceptions (especially Denmark), the institutional effects that we had expected to find are small or non-existent. 


\section{TABLE 6}

Wage Premia and Penalties Associated with HR Practices: (by Type of Economy and by Country) ${ }^{\mathrm{a}}$

$\begin{array}{ccc}\begin{array}{c}\text { High-involvement } \\ \text { work }\end{array} & \begin{array}{c}\text { Monitoring } \\ \text { intensity }\end{array} & \begin{array}{c}\text { Performance } \\ \text { pay: Incidence }\end{array}\end{array}$

Liberal market economies

$\begin{array}{llll}\text { All } & 0.082^{* * *} & -0.063^{* * *} & 0.059^{* * *} \\ \text { US } & 0.144^{* * *} & -0.079^{* * *} & 0.103^{* *} \\ \text { Canada } & 0.049^{* * *} & -0.036^{* *} & 0.020 \\ \text { UK } & 0.019+ & -0.053^{* * *} & 0.062^{*}\end{array}$

Co-ordinated market economies

All

Austria

Denmark

France

Germany

Spain

$$
\begin{aligned}
& 0.049 \\
& 0.072^{* * *} \\
& 0.011 \\
& -0.028^{* *} \\
& 0.107^{* * *} \\
& 0.094^{* * *}
\end{aligned}
$$

$-0.025^{*}$

$-0.058 * * *$

0.001

$-0.007$

$-0.039 *$

$-0.080 * * *$
$0.039^{*}$

$0.057^{* *}$

0.042

$0.039 * * *$

$0.074 * * *$

0.015

Significant at $p<0.10=+; p<0.05=* ; p<0.01=* * ; p<0.001=* * *$.

a This table summarizes the results of regression analyses. It shows the coefficients on wages and their level of significance for liberal market economies as a whole, co-ordinated economies as a whole, and for each of the countries in these two categories. 


\section{Discussion and interpretation}

In order to interpret these findings from an institutional perspective, we need to combine the results from both our incidence models and our wage models. From this perspective, Denmark stands out as the exceptional case-the one that most conforms to the expected findings based on prior institutional research. Compared with liberal market countries, Denmark makes significantly greater use of high-involvement work design and less use of monitoring and performance-based pay, as expected. Moreover, in centers that make greater use of these practices, workers receive no wage premium or penalty. These results are consistent with the classic description of a coordinated economy, where high union density, union power and the presence of workplace shop stewards appear to secure a high-involvement approach to work design, high trust (low monitoring) and conformity in wage setting, regardless of differences in HR practices.

The US case similarly conforms to our expectations of the most extreme liberal market case. On average, US workplaces have high levels of taylorized work design and more intensive performance monitoring accompanied by the highest use of performance-based pay. In addition, the relationship between wages and workplace practices in the USA is the largest and most significant of any country.

Between these two extremes, the patterns of some countries are consistent with institutional explanations, but many are not. Consistent with our predictions, the UK and Canada resemble the US in a number of respects, with high use of taylorized work design and intensive monitoring; and these practices, in turn, are associated with significant wage effects. However, contrary to our predictions, Canada and the UK make much less use of performance-based pay; and for Canada, this practice carries no wage premium.

The findings for France are somewhat consistent with prior research. Recall that French call centers have high levels of taylorization (on par or slightly higher than the US). Overall, their work practices resemble those found in US centers - with taylorized work design, intensive monitoring and high use of performance-based pay. This pattern is consistent with longstanding research on the hierarchical organization of French firms compared, for example, to German firms (Lorenz and Valeyre 2005; Maurice et al. 1986). It is also consistent with Marsden et al. (2007) findings that work autonomy and use of performance-based pay are inversely related in France. Similarly, French unions have little influence over hierarchical workplace design due to low union membership levels, weak works councils and fragmented political local unions. Moreover, given considerable 'wage rigidity' from centralized bargaining, French employers have had strong incentives to adopt performance-based pay, or what is referred to as the 'individualization of pay' (Marsden et al. 2007). However, it has remained a relatively small percentage of overall pay, and thus, while it does contribute significantly to higher pay, the wage premium is not substantial (those call centers that use performance-based pay have a 3.9 per cent higher wage compared with those that do not). (Note that when we measured performance-based pay in the French case, we excluded the practice of profitsharing - so-called 'participation' - that has diffused widely because it is supported by French fiscal policy).

The results for the relationship between work organization and pay in France do not conform to our expectations. Note that France is the only country where we observe a wage penalty for use of high-involvement work practices. Based on the fieldwork of the French team, one plausible interpretation for this finding is that our survey captured a particular institutional story concerning the transition from a 39-hour to 35-hour work week. When the 35-hour law was first passed, a majority of large firms rapidly introduced the 35-hour regime in exchange for two concessions from unions: the introduction of flexible work organization and teams (similar to our definition of high-involvement work organization) and wage moderation or even a freeze on wage increases for several years. Thus, many French workers effectively accepted a lower wage in exchange for better working conditions, or most probably, a better balance between work and family life.

Austria and Germany present more contradictory patterns. Like Denmark, most call centers offer highdiscretion jobs, teamwork and low levels of performance monitoring, and these patterns are consistent with our expectations. However, like the USA, there are large and significant wage effects associated with the use of all three HR practices. The recent history of fragmentation in bargaining can help explain this pattern for Germany (Bosch and Weinkopf 2008) and more specific studies of union strategies for call centers show that there are large differences in bargaining coverage and contractual agreements across industries and even firms in the same industry (Holst 2008). Thus, employers have considerable leeway in their approach to HR practices and pay setting, particularly in this new sector of service activities. The results for Austria, however, are more perplexing. Not only does the Austrian IR system remain more stable and centralized than the German system, but Austrian unions were successful in incorporating call centers, including subcontractors, into their overarching system of collective 
representation. Nonetheless, the Austrian unions have not been successful in preventing competition based primarily on labor costs in this sector or the extensive use of freelancers who receive considerably less pay than workers on standard contracts; and recent research suggests that wage dispersion in call centers is actually higher in Austria than in Germany (Holst 2008).

Finally, Spain closely resembles France in following the US model. The average Spanish centre makes extensive use of taylorized work practices, monitoring and performance-based pay, with substantial wage premia and penalties for the first two practices. Like France, the Spanish industrial relations system features centralized bargaining and quasi-mandatory extensions of negotiated contracts, but low levels of union density or collective representation or works councils at the firm or establishment level. Thus, similar to France, Spanish employers have considerable prerogative to enact hierarchical forms of work organization and performance monitoring.

In sum, expectations based on the varieties of capitalism literature, about the differences between coordinated and liberal market economies, do not seem to hold well for this (emerging) service sector. With some exceptions, our analyses of the incidence of HR practices are relatively consistent with prior research on the organization of work at the firm level, with greater use of high-involvement practices in Austria, Denmark and Germany, and lower use in France, Spain and the liberal market economies. However, the results of our wage analyses are consistent with an overall pattern of market liberalization in the coordinated economies, with greater variation in pay associated with HR practices at the establishment level.

\section{Limitations}

There are important limitations to this study. The single-respondent nature of the data may overstate the relationship between earnings and other factors. We attempted to overcome this limitation by using relatively objective and context-specific survey questions that were tested in field settings in each country prior to survey administration. In addition, we have no reason to believe that any inflation in correlations among variables should be greater in one country than another.

More importantly, our cross-sectional design does not allow us to assess causality. Nonetheless, we did a number of things to rule out alternative explanations. Our human capital and organizational controls are comparable to those found in other organizational studies of wages (e.g. Batt 2001; Osterman 2006); and in additional analyses, controls for sales growth and employee turnover rates did not alter the findings, nor did the inclusion of local labor market conditions for the US analysis. Our findings therefore identify relationships between pay and work practices, whether these are similar or different within and across countries, and whether these patterns conform to the prior literature on varieties of capitalism.

\section{Conclusions}

In this article, we examined whether establishment-level wages are related to different approaches to HR management. We also assessed whether there are differences between coordinated and liberal market economies and among the countries in each of these groups. We first analyzed variation in the adoption of high-involvement work design and performance management techniques. We found that coordinated economies as a group are significantly different only in their lower use of performance monitoring. Country-level differences explain more of the variation in adoption of HR practices. These findings held after controlling for a large number of human capital, organizational and institutional factors.

In our analysis of wages, we found an overall positive relationship between establishment-level wages and high-involvement work design. While several prior studies have found this relationship to hold for manufacturing (e.g. Bailey et al. 2001; Hamilton et al. 2003; Helper et al. 2002; Osterman 2006), ours is among the first studies to substantiate this finding for service workplaces. Given that the context of our study is routine service work in call centers, where workers typically have low levels of discretion, our findings are likely to generalize to more complex services where the importance of workplace skills, discretion and knowledge are more pronounced. Moreover, compared with prior research, our study suggests greater generalizability of this relationship in that it holds across radically different national institutional environments.

In contrast to high-involvement work design, the use of intensive performance monitoring is significantly negatively related to wages. The prior literature on this topic has discussed two alternative hypotheses. On the one hand, performance monitoring systems are typically used in easy-to-monitor jobs - jobs that have low skill 
requirements and thus, would be expected to pay low wages. On the other hand, the stress associated with onerous electronic monitoring might lead to the payment of compensating differentials. Our results support the first line of reasoning. The French case presents an exception to this finding, and here we believe there is a particular institutional explanation related to the introduction of the 35 hour work week, where workers are willing to accept lower wages in exchange for better working conditions and better work-family balance.

Our findings for the positive effect of performance-based pay are consistent with some prior research on this topic (e.g. Bryson and Freeman 2006). On average, establishments that use performance-based pay offer wages that are 5.7 per cent higher than those that do not use this practice. However, we found no wage premium for three of the countries in our study: Canada, Denmark and Spain.

Finally, we found that the coordinated versus liberal market categories, as developed in the varieties of capitalism literature, did not provide a very useful lens for explaining variation in the adoption of HR practices and their relationship with wages. We did find that national institutions explain some variance in the adoption of $H R$ practices, consistent with our expectations, but not in the relationship between these practices and wages. The Danish case is the exception. But overall, we found that wages were significantly related to most HR practices in most countries. This suggests a level of wage flexibility at the workplace level that is at odds with prior research on industrial relations systems in continental Europe. While we would have expected to find this pattern in countries, such as Germany, that have experienced considerable decentralization in collective bargaining, we found the same pattern in countries such as Austria, France and Spain, where centralized industrial relations systems remain quite robust. Thus, our findings point to an overall trend towards greater labor market liberalization, at least in new service activities where union power is weak.

\section{Acknowledgements}

This study is based on the Global Call Centre Research Project, a description of which can be found at http://www.globalcallcenter.org. Generous support for the country studies came from the Russell Sage Foundation (the USA, Denmark, France, Germany, the UK); the Alfred P. Sloan Foundation (the USA); the Economic and Social Research Council and the UK Customer Contact Association (the UK); CNRS - Centre National de la Recherche Scientifique and AFRC (Association Francoise des Centres de Relation Client - French Employers Association of Call Centers) (France); the Hans Boechler Foundation (Germany); FWF Austrian Science Fund and Jubiläumsfonds der Österreichischen Nationalbank (Austria); Social Sciences and Humanities Research Council of Canada and InterUniversity Research Centre on Globalization and Work (Canada); and the AIRE program (University Rovira \& Virgili) CIDEM (Catalan Government) (Spain).

\section{Notes}

1. Personal communication, David Marsden.

2. For technical reports with full descriptions of each country survey, see: Austria (Schönauer 2005), Canada (van Jaarsveld et al. 2006), Denmark (Sørensen and El-Salanti 2005), France (Lanciano-Morandat et al. 2005), Germany (Scholten and Holtgrewe 2006), Spain (Valverde et al. 2006), UK (Holman et al. 2005); the US (Batt et al. 2005).

3. For more complete analyses of the factors that shape the adoption and outcomes of performance monitoring, see Doellgast et al. (2009) and Holman et al. (2009). Slight differences in coefficients and levels of significance in these analyses reflect differences in model specifications and sample sizes.

4. Note that this finding differs substantially from the bi-variate correlations found in Appendix 4, where union coverage is significantly negatively related to wage levels. That is because union coverage is higher in some low wage countries (e.g. Spain), while union coverage is low in some high wage countries (e.g. the USA). Once country location is taken into account, we find an overall positive and significant relationship between union coverage and wage level.

5. Note that the pooled data analysis (model 1) used a Huber-sandwich estimator because of the nonindependence of observations within groups (countries). However, for analyses with only a few clusters (models 2 and 3), the Hubersandwich estimator may introduce more variability because there is not enough information to estimate between group variance (Kauermann and Carroll 2001); and in this case, using the Huber-Sandwich correction with repeated estimations using the bootstrap method provides a more precise estimate of the 
standard errors and the significance levels (Carroll et al. 1998: 10) We have followed this approach in models 2 and 3. We also ran these analyses using the pooled data and interaction terms for the coordinated and liberal market groups; and the results using both approaches were the same.

\section{References}

Appelbaum, E., Bailey, T., Berg, P. and Kalleberg, A. (2000). Manufacturing Advantage. Ithaca, NY: Cornell University Press.

Arthur, J. (1994). 'Effects of human resource systems on manufacturing performance and turnover'. Academy of Management Journal, 37: 670-87.

Bailey, T., Berg, P. and Sandy, C. (2001). 'The effect of high performance work practices on employee earnings in the steel, apparel, and medical electronics and imaging industries'. Industrial and Labor Relations Review, 54 (2): 525-43.

Barker, J. (1993). 'Tightening the iron cage: concertive control in self-managing teams'. Administrative Science Quarterly, 38: 408-37.

Bartel, A. (2004). 'Human resource management and organizational performance: evidence from retail banking'. Industrial and Labor Relations Review, 57 (2): 181-203.

Batt, R. (1999). 'Work organization, technology, and performance in customer service and sales'. Industrial and Labor Relations Review, 52 (4): 539-64.

- (2001). 'Explaining intra-occupational wage inequality in telecommunications services: customer segmentation, human resource practices, and union decline'. Industrial and Labor Relations Review, 54 (2A): $425-49$.

- (2002). 'Managing customer services: human resource practices, quit rates, and sales growth'. Academy of Management Journal, 45 (3): 587-97.

--, Doellgast, V. and Kwon, H. (2005). 'The US Call Centre Industry: Strategy, HR practices, and Performance'. National Benchmarking Report. http://www.globalcallcenter.org.

- - and Nohara, H. (2009). 'How institutions and business strategies affect wages: a cross national study of call centers'. Industrial and Labor Relations Review, 62 (4):533-52.

Bauer, T. and Bender, S. (2001). 'Flexible Work Systems and the Structure of Wages: Evidence from Matched Employer-Employee Data'. IZA Paper No. 353. Bonn, Germany.

Black, S., Lynch, L. and Krivelyova, A. (2004). 'How workers fare when employers innovate'. Industrial Relations, 43 (1): 44-66.

Blanchflower, D. and Bryson, A. (2003). 'Changes over time in union relative wage effects in the UK and the US revisited'. In J. Addison and C. Schnabel (eds), International Handbook of Trade Unions. Cheltenham, England and Northamption, MA: Elgar, chapter 7, pp. 197-245.

Blau, F. and Kahn, L. (1999). 'Institutions and laws in the labor market'. In O. Ashenfelter and D. Card (eds), Handbook of Labor Economics, Vol. 3. Amsterdam: Elsevier, pp. 1399-461.

Bosch, G. and Weinkopf, C. (eds) (2008). Low Wage Work in Germany. New York: Russell Sage Foundation.

Brown, W., Marginson, P. and Walsh, J. (2003). 'The management of pay as the influence of collective bargaining diminishes'. In P. Edwards (ed.), Industrial Relations: Theory and Practice in Britain, 2nd edn. Oxford, UK: Blackwell, pp. 189-213.

Bryson, A. and Forth, J. (2006). 'The Theory and Practice of Pay Setting'. Manpower Human Resources Lab. MHRLdp001. London School of Economics and Political Science. December.

- - and Freeman, R. (2006). 'Doing the Right Thing? Does Fair Share Capitalism Improve Workplace Performance?' Mimeo.

Calmfors, L. and Driffill, J. (1988). 'Bargaining structure, corporatism and macroeconomic performance', Economic Policy, 6, 12-61.

Cappelli, P. (1996). 'Technology and skill requirements: implications for establishment wage structures'. New England Economic Review, (May-June): 138-54.

- - (ed.) (1999). Employment Practices and Business Strategy. Oxford: Oxford University Press.

Caroli, E. and Gautie, J. (eds) (2008). Low Wage Work in France. New York: Russell Sage Foundation.

Carroll, R. J., Wang, S., Simpson, D. G., Stromberg, A. J. and Ruppert, D. (1998). 'The Sandwich (Robust Covariance Matrix) Estimator'. January 26. Unpublished Paper. 
Coutrot, T. (2000). 'Innovations dans le travail: la pression de la concurrence internationale, l'atout des qualifications: Première Synthèse'. Dares. $\mathrm{N}^{\circ} 9.2$.

Doellgast, V. (2008). 'Collective bargaining and high involvement management in comparative perspective: evidence from US and German call centers'. Industrial Relations, 47 (2): 284-319.

--, Holtgrewe, U. and Deery, S. (2009). 'The effects of national institutions and collective bargaining arrangements on job quality in front-line service workplaces'. Industrial and Labor Relations Review, 62 (4): 489-509.

Doeringer, P. and Piore, M. (1971). Internal Labor Markets and Manpower Analysis. Lexington, MA: Heath and Co.

Eisenhardt, K. (1988). 'Agency and institutional theory explanations: the case of retail sales compensation'. Academy of Management Journal, 31 (3): 488-511.

Fernie, S. and Metcalf, D. (1998). (Not) Hanging on the Telephone: Payment Systems in the New Sweatshops. Working Paper 370. London: Centre for Economic Performance London School of Economics and Political Science.

Forth, J. and Millward, N. (2004). 'High-involvement management and pay in Britain'. Industrial Relations, 43 (1): 98-119.

French, M. and Dunlap, L. (1998). 'Compensating wage differentials for job stress'. Applied Economics, 30 (8): 1067-75.

Gautie, J. and Schmidt, J. (eds) (2010). Low Wage Work in a Wealthy World. New York: Russell Sage Foundation.

Gerhart, B., Wright, P., McMahan, G. and Snell, S. (2000). 'Measurement error in research on the human resources and firm performance relationship: how much error is there and how does it influence effect size estimates?'. Personnel Psychology, 53: 803-34.

Greenan, N. (1996). 'Innovation technologique, changements organizationnels et evolution des compétences'. Economie et Statistique, 298: 15-34.

Hall, P. and Soskice, D. (2001). Varieties of Capitalism: The Institutional Foundations of Comparative Advantage. Oxford: Oxford University Press.

Hamilton, B., Nickerson, J. and Owan, H. (2003). 'Team incentives and worker heterogeneity: an empirical analysis of the impact of teams on productivity and participation'. Journal of Political Economy, 111: 465-97.

Handel, M. and Gittleman, M. (2004). 'Is there a wage payoff to innovative work practices?'. Industrial Relations, 43 (1): 67-97.

- - and Levine, D. (2004). 'Editors' introduction: the effects of new work practices on workers'. Industrial Relations, 43 (1): 1-42.

Helper, S., Levine, D. and Bendoly, E. (2002). 'Employee involvement and pay at American auto suppliers'. Journal of Economic Management and Strategy, 11 (2): 329-77.

Holman, D., Batt, R. and Holtgrewe, U. (2007). 'The Global Call Centre Report: International Perspectives on Management and Employment'. http://www.globalcallcenter.org.

- - Frenkel, S., Sorensen, O. and Wood, S. (2009). 'Work design variation and outcomes in call centers: Strategic choice and institutional explanations'. Industrial and Labor Relations Review, 62 (4): 510-32.

- - Wood, S. and Stride, C. (2005). Human Resource Management in U.K. Call Centres. Sheffield: Institute of Work Psychology in association with the Call Centre Association, University of Sheffield.

Holst, H. (2008). 'The political economy of trade union strategies in Austria and Germany: the case of call centres'. European Journal of Industrial Relations, 14 (1):25-45.

Jackson, G. and Deeg, R. (2006). 'How Many Varieties of Capitalism?: Comparing the Comparative Institutional Analyses of Capitalist Diversity'. MPIfG Discussion Paper 06/2, Max-Planck-Institut für Gesellschaftsforschung, Köln. http://www.mpi-fg-koeln.mpg.de/pu/mpifg_dp/dp06-2.pdf.

Katz, H. and Darbishire, O. (2000). Converging Divergences: Worldwide Changes in Employment Systems. Ithaca, NY: ILR Press Books.

Kauermann, G. and Carroll, R. J. (2001). 'A note on the efficiency of sandwich covariance matrix estimation'. Journal of the American Statistical Association, 94 (456): 1387-96.

Lanciano-Morandat, C., Nohara, H. and Tchobanian, R. (2005). 'French Call Centre Industry Report, 2004'. http://www.globalcallcenter.org.

Lester, R. (1952). 'A range theory of wage differentials'. Industrial and Labor Relations Review, 5: 483-500.

Levine, D., Belman, D., Charness, G., Groshen, E. and O'Shaughnessy, K. C. (2003). Changes in Careers and Wage Structures at Large American Employers. Kalamazoo, MI: Upjohn Institute. 
Lorenz, E. and Valeyre, A. (2005). 'Organizational innovation, human resource management and labor market structure: a comparison of the EU-15'. The Journal of Industrial Relations, 47 (3): 424-42.

MacDuffie, J. P. (1995). 'Human resource bundles and manufacturing performance'. Industrial and Labor Relations Review, 48: 197-201.

Marginson, P., Arrowsmith, J. and Sisson, K. (2003). 'Between decentralization and Europeanization: sectoral bargaining in four countries and two sectors'. European Journal of Industrial Relations, 9 (2): $163-87$.

Marsden, D., Belfield, R. and Benhamou, S. (2007). 'Incentive Pay Systems and the Management of Human Resources in France and Great Britain'. CEP Discussion Paper 796. Centre for Economic Performance. London School of Economics and Political Science. May.

Maurice, M., Seller, F. and Silvestre, J. (1986). The Social Foundations of Industrial Power. Cambridge, MA: MIT Press.

Millward, N., Forth, J. and Bryson, A. (2000). Changes in Employment Relations, 1980-1998, Britain at Work: As Depicted by the 1998 Workplace Employee Relations Survey. Oxford: Routledge.

Ochel, W. (2005). 'Decentralizing wage bargaining in Germany - a way to increase employment?'. Labor, 19 (1): 91-121.

Osterman, P. (1987). 'Choice of employment systems in internal labor markets'. Industrial Relations, 26 (1): $46-67$.

- - (2000). 'Work reorganization in an era of restructuring: trends in diffusion and effects on employee welfare'. Industrial and Labor Relations Review, 53 (2): 179-96.

- - (2006). 'The wage effects of high performance work organization in manufacturing'. Industrial and Labor Relations Review, 59 (2): 187-204.

Pendleton, A., Whitfield, K. and Bryson, A. (2009). 'The changing use of contingent pay at the modern British workplace'. In W. Brown, A. Bryson, J. Forth and K. Whitfield (eds.), The Evolution of the Modern Workplace. Cambridge: Cambridge University Press, pp. 256-84.

Piore, M. (1979). Birds of Passage: Migrant Labor in Industrial Societies. Cambridge: Cambridge University Press.

Scholten, J. and Holtgrewe, U. (2006). 'The Global Call Centre Industry Projekt - Deutschland: Erste Ergebnisse der Telefonumfrage fr Deutschland'. No. 2/2006, Duisburger Beitrzur Soziologischen Forschung.

Schönauer, A. (2005). Qualität der Arbeit in Callcentern. Fallstudie Österreich im Global Call Center Industry Project. FORBA Forschungsbericht 5/2005. Available at: http://www.forba.at/files/download/download.php?_mmc=czo2OiJpZD0xNDliOw

Silvestre, J.-J. (1978). Les Inégalités De Salaries: Marché Du Travail Et Croissance Economique. Pairs: Presse Universitaire de France.

Sørensen, O. and El-Salanti, N. (2005). Call Centers in Denmark 2004: Strategy, HR Practices, and Performance. Report for the Russell Sage Foundation. Available at: http://www.globalcallcenter.org

Streeck, W. and Thelen, K. (eds.) (2005). Beyond Continuity: Explorations in the Dynamics of Advanced Political Economies. Oxford: Oxford University Press.

Traxler, F. (2003). 'Bargaining, state regulation and the trajectories of industrial relations'. European Journal of Industrial Relations, 9 (2): 141-61.

Valverde, M., Gorjup, M. T., Martí, N., Ryan, G. and Villarroya, M. (2006). The Call Center Sector in Spain: Performance, Strategies and Human Resource Management Practices. Report. Grup de Recerca Factor Humà, Organitzacions i Mercats (FHOM), Departament de Gestió d’Empreses, Universitat Rovira i Virgili, Reus, Spain.

van Jaarsveld, D., Frost, A. and Walker, D. (2006). Canadian Call Center Report. Vancouver, University of British Columbia. Available at: http://www.globalcallcenter.org

Visser, J. (2006). 'Union membership statistics in 24 countries'. Monthly Labor Review, January: 38-49.

Westergaard-Nielsen, N. (ed.) (2008). Low Wage Work in Denmark. New York: Russell Sage Foundation. 


\section{Appendix 2: Variable Definitions} Dependent variable
Median gross annual
earnings $(\log )$
The gross annual earnings of the 'typical full-time core employee'. (Typical means that about half the core employees are paid more and about half are paid less). Gross annual earnings include total earnings before deductions and taxes. It includes wages, bonuses, commissions and profit sharing. It excludes overtime pay, benefits such as pensions and health, and deferred compensation such as stock options.

Independent variables

Work organization and performance management

High-involvement An index based on 2 items:

work organization - Discretion: an 8-item index of discretion over tasks, tools, pace of work, breaks, work methods, what to say to customers, handling additional customer requests, handling customer complaints (each item measured (alpha $=0.77$ )

- Group work: the average percent of workers in off-line problem-solving or on-line self-directed work groups.

\section{Performance monitoring}

Performance-based pay
An index based on three items: How often core employees receive statistics on performance; how often their calls are listened to by supervisors; and how often they get feedback on phone technique (Frequency scale of $1-8$, where $1=$ never and $8=$ daily) $($ Alpha $=0.66)$.

The percent of pay based on individual commission or group performance (group-based or profit sharing; in France, does not include profit sharing - company-level 'participation' - that has been affected by national legislation).

Control Variables

Human capital and demographic characteristics

Education to age 16 Typical core employee has completed education to age 16 (omitted category).

Education to age 18 Typical core employee has completed education to age 18.

Education: University Typical core employee has completed university degree or equivalent degree

Firm-specific training $\log$ of the number of weeks it takes for a full-time core employee to become fully competent on the job (E.g. so that they are able to train someone else).

$\%$ workforce: Female The percentage of core employees who are women.

Institutional, organizational and market characteristics

Union coverage

Whether the call centre is covered by collective bargaining for core employees.

Customer: Large bus. Primary customer of call centre is large business ( $1=$ large business; else 0 ).

Technology use

An additive index of 5 types of call centre technology for interacting with customers: email, fax, web enablement, electronic customer relationship management and Voice over Internet Protocol.

Ownership: In-house

Whether the call centre is an in-house operation providing services to clients of one company or is a sub-contractor providing services to other companies. $(1=$ In-house; sub-contractor $=0)$.

Part of larger organization

Size $(\ln )$

Age of centre (ln yrs.)

Task: Service only

Call type: Inbound

Sector: Financial

Sector: Telecom
Call centre is part of an organization with multiple call centres.

Log of the number of call centre agents in the establishment.

Log of years since the call centre was established.

Primary task is to provide services only, not sales $(1=$ service only; else 0 ).

Largest volume of calls to the centre are inbound $(1=$ In bound; outbound $=0$ ).

In-house centre serving financial services $(1=$ Financial services, else 0$)$.

In-house centre serving telecommunications $(1=$ Telecommunications, else 0 ). 